\title{
Compensatory growth, energy storage and behavior of juvenile Pacific halibut Hippoglossus stenolepis following thermally induced growth reduction
}

\author{
Thomas P. Hurst ${ }^{1, *}$, Mara L. Spencer ${ }^{1}$, Susan M. Sogard ${ }^{1,2}$, Allan W. Stoner ${ }^{1}$ \\ ${ }^{1}$ Fisheries Behavioral Ecology Program, Alaska Fisheries Science Center, National Marine Fisheries Service, NOAA, \\ Hatfield Marine Science Center, Newport, Oregon 97365, USA \\ ${ }^{2}$ Present address: Southwest Fisheries Science Center, National Marine Fisheries Service, NOAA, 110 Shaffer Road, \\ Santa Cruz, California 95060, USA
}

\begin{abstract}
For fishes settling over wide areas, spatial temperature variation can have a significant impact on growth rates during the early juvenile period. Size variation within cohorts and across years will depend on the thermal sensitivity of growth rate, the ability to move to favorable growth environments, and the potential to compensate for periods of reduced growth. We examined the growth, behavior and energy storage responses of juvenile Pacific halibut Hippoglossus stenolepis exposed to a thermally induced reduction in growth. Halibut reared for $12 \mathrm{wk}$ at $2^{\circ} \mathrm{C}$ then acclimated to and grown at $10^{\circ} \mathrm{C}$ (delayed treatment) were compared to fish reared continuously at $10^{\circ} \mathrm{C}$ (controls). Growth rates at $2{ }^{\circ} \mathrm{C}$ were $25 \%$ of those at $10^{\circ} \mathrm{C}$, resulting in a 2.4 -fold difference in mass after 12 wk. Following acclimation to $10^{\circ} \mathrm{C}$, specific growth rates of delayed fish were $20 \%$ higher than controls. Complete compensation would have required $35 \mathrm{wk}$, assuming maintenance of observed growth rate differences between treatments. Rapid growth during the compensation phase was probably due in part to a reduction in the allocation of energy to lipid storage: length-corrected lipid levels of delayed fish were $14 \%$ lower than levels among control fish. Behavioral observations indicated that growth compensating fish were more active than control fish; this is assumed to reflect increased foraging activity. However, when presented with food, growth-compensating halibut did not initiate feeding more rapidly than control fish. The predation and starvation risks associated with increased activity and decreased energy storage appear to represent trade-offs with rapid compensatory growth in juvenile halibut.
\end{abstract}

KEY WORDS: Pacific halibut · Hippoglossus stenolepis - Thermal variation · Compensatory growth • Energy storage $\cdot$ Behavior Resale or republication not permitted without written consent of the publisher

\section{INTRODUCTION}

Fish cohorts are composed of individuals with variable growth histories resulting from spatial and temporal patterns in temperature and prey availability, the major regulators of growth and development in fishes. For species settling over a wide area, thermal gradients may be the primary regulator of post-settlement growth and survival (Bergman et al. 1988, Kamermans et al. 1995). In addition to the effects of interannual variation (King et al. 1999, Ottersen \& Loeng 2000), seasonal variation may expose early-spawned cohorts to a significantly different thermal environment than later-spawned cohorts (Rutherford \& Houde 1995, Chui \& Chen 2001). Whereas thermal variation represents a variability-generating factor with respect to growth (sensu van der Veer et al. 1994), habitat selection represents a variability-dampening factor. Ultimately, size variation within cohorts and across years depends on the levels of genetic and environmental variation in growth rate, the ability of individuals to select habitats offering the greatest growth potential, 
and the size-specific patterns of survival. The potential to compensate for periods of reduced growth may further offset some of the variation in body size generated by differences in habitat quality.

Many fish species respond to periods of growth disruption with subsequent elevations of consumption and growth rate (see Ali et al. 2003 for review). This compensatory growth response has been well-documented in a wide variety of fish species, and its potential utility in aquaculture settings has been routinely explored (e.g. Gaylord \& Gatlin 2001). Most research on the capacity for compensatory growth has examined responses to periods of food restriction or deprivation (Jobling et al. 1994, Paul et al. 1995, Sogard \& Olla 2002). However, compensatory feeding and growth responses have also been observed in response to growth reductions resulting from oxygen depletion (Bejda et al. 1992, Foss \& Imsland 2002), delay in diet switch (Buckel et al. 1998), and reduced temperatures (Mortensen \& Damsgård 1993, Nicieza \& Metcalfe 1997).

During the first year of life, Pacific halibut Hippoglossus stenolepis can be exposed to a wide range of temperatures; as such they represent a useful model for the study of temperature effects on growth. Age-0 halibut are distributed on sandy substrates of the continental shelf at depths from 5 to $70 \mathrm{~m}$ (Norcross et al. 1995, 1997, Stoner \& Abookire 2002). In addition to the seasonal cycle, there is a pronounced spatial variability in summer bottom temperatures in the Bering Sea due to the persistence of sea ice and the presence of a subsurface layer of cold water. The cold layer can cover much of the continental shelf in some years, but is broken down by solar heating and tidal mixing in the nearshore areas (Luchin et al. 1999). Temperatures below $2^{\circ} \mathrm{C}$ have been observed on the middle shelf in June, whereas nearshore waters can reach $13^{\circ} \mathrm{C}$ in some summers (Stabeno et al. 2001). Similar though less dramatic temperature gradients exist in the Gulf of Alaska (Reed \& Schumacher 1986). Consequently, settlement into low temperature habitats followed by short migrations or ocean mixing can expose juvenile halibut to significant temperature changes during the first year of life, independent of the underlying seasonal cycle. The consequences of such variable thermal histories for growth and survival are unknown.

In this study we examine the consequences of variation in the thermal history of juvenile Pacific halibut. Specifically, we describe a compensatory growth response to a period of thermally induced growth suppression. In order to evaluate the physiological mechanisms and survival consequences of elevated growth rates, we describe the behavior and energy storage levels of fish following a period of low-temperature exposure relative to controls reared continuously at high temperatures.

\section{MATERIALS AND METHODS}

Collection and holding. Juvenile halibut (Age-0, 25 to $40 \mathrm{~mm}$ total length, TL) were collected with a $2 \mathrm{~m}$ beam trawl from shallow nursery grounds in the vicinity of Kodiak Island, Alaska, in August 2001. After being held for several days in ambient seawater at the Alaska Fisheries Science Center's (AFSC) Kodiak laboratory, halibut were shipped to the AFSC laboratory in Newport, Oregon. For transport, fish were packed in plastic bags filled with seawater and oxygen, and shipped in insulated containers. Time from packing to arrival in Newport was approximately $30 \mathrm{~h}$.

Prior to experimental use, fish were reared in $47 \times$ $74 \mathrm{~cm}$ square or $122 \mathrm{~cm}$ diameter round tanks with a thin layer of sand substrate. Tanks were maintained at $9^{\circ} \mathrm{C}$ with a photoperiod of $17 \mathrm{~h}: 7 \mathrm{~h}$ light:dark, similar to summer conditions at the collection site. Fish were fed to satiation 3 times per week, initially on frozen shrimp (Artemia sp.) then on commercially available moist food (BioDiet, 1 to $3 \mathrm{~mm}$ pellets).

Growth experiment. The growth experiment consisted of 2 phases. The temperature phase measured the effect of reduced temperatures on halibut growth and generated the variation in growth history required to elicit a compensatory response. In the compensation phase, we tested the potential for compensatory growth among juvenile halibut in response to the previous thermally induced growth-rate reduction.

At the start of the growth experiment, 40 fish were weighed (to $0.01 \mathrm{~g}$ wet mass), measured (to $1 \mathrm{~mm} \mathrm{TL}$ ), and randomly assigned to 20 tanks ( 2 fish $\operatorname{tank}^{-1}$ ). We assigned 10 tanks to each of the 2 experimental treatments. Tanks were $701(66 \times 45.7 \times 23.2 \mathrm{~cm})$, contained a thin layer of sand substrate, and were supplied with flow-through seawater at a rate of $30 \mathrm{ml} \mathrm{s}^{-1}$. Fish sizes $( \pm 1 \mathrm{SD})$ were $66 \pm 5 \mathrm{~mm}$ TL and $2.60 \pm 0.55 \mathrm{~g}$ wet mass at the start of the experiment and did not differ significantly between temperature treatments (ANOVA, $p>0.10$ ). During the experiment, fish were fed to satiation 3 times per week on $3 \mathrm{~mm}$ Biodiet pellets. All fish were remeasured (length and mass) at 2 wk intervals.

Temperatures in half of the tanks (controls) were maintained at $10^{\circ} \mathrm{C}$ through both phases of the experiment (total $20 \mathrm{wk}$ ). Temperatures in the remaining tanks (subsequently referred to as the 'delayed treatment') were lowered to $2{ }^{\circ} \mathrm{C}$ at a rate of $1^{\circ} \mathrm{C} \mathrm{d}^{-1}$ for the temperature phase. After $12 \mathrm{wk}$, temperatures in the $2^{\circ} \mathrm{C}$ tanks were raised back to $10^{\circ} \mathrm{C}$ over a period of $7 \mathrm{~d}$ for the compensation phase. These fish were reared for $13 \mathrm{wk}$ following the temperature transition (total $26 \mathrm{wk}$ ). At the end of the compensation phase, all fish were measured, weighed, sacrificed with an overdose of anesthetic (MS-222) and frozen for compositional analysis. 
Growth rates in each phase of the experiment were analyzed by 2-way ANOVA with temperature treatment and fish rank (see next paragraph) as main factors. Growth rates in length $\left(\mathrm{mm} \mathrm{d}^{-1}\right)$ and mass (specific growth rate $\mathrm{d}^{-1}$ ) were determined for individual fish by regression of total length and ln-mass against sampling dates. Biphasic regression indicated that growth rates of delayed fish increased significantly approximately $5 \mathrm{wk}$ after the temperature change, reflecting acclimation to the higher temperature. Hence, growth rates of the delayed fish during the compensation phase were calculated using data from Weeks 18 to 26. In order to account for size-dependent changes in growth rates, the growth rates of delayed fish during the compensation phase were compared to those of control fish measured over a similar size range (Weeks 6 to 18, Fig. 1).

Preliminary observations of growth data and fish behavior suggested the presence of a social structure between the 2 fish in each tank. The larger fish responded to the introduction of food more rapidly than the smaller fish. When growth rates of the 2 fish differed, the larger of the 2 always grew faster. Differences in growth between the 2 fish were greatest among control fish in the compensation phase, when initial size differences were largest. For clarity, we refer to the larger and smaller of the fish in each tank as the dominant and subordinate, respectively. Statisti-

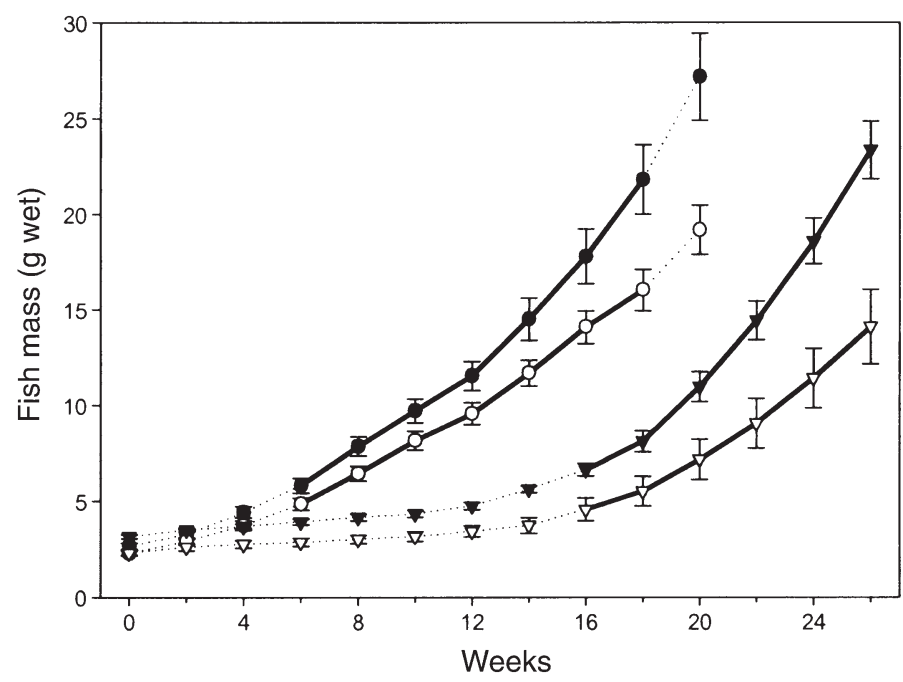

Fig. 1. Hippoglossus stenolepis. Growth trajectories of juveniles. $(\bullet, 0)$ : $10^{\circ} \mathrm{C}$ control treatment; $(\boldsymbol{\nabla}, \nabla)$ : delayed treatment switched from 2 to $10^{\circ} \mathrm{C}$ following Week 12. Filled and open symbols represent 'dominant' and 'subordinate' fish within each temperature treatment. Each data point is the mean $( \pm \mathrm{SD})$ of 10 fish in each treatment. Continuous portions of lines indicate experimental periods used in comparison of compensation phase growth rates; temperature phase growth rates were calculated over Weeks 0 to 12 for all fish cal analyses of growth rate and lipid storage were carried out by considering fish size rank (dominant versus subordinate) as an independent variable.

Energy allocation. To determine if fish in the 2 thermal regimes allocated energy between growth and storage differently, lipid content was measured for all halibut following the compensation phase of the experiment, using the methods of Hurst et al. (2000). Briefly, fish were thawed and otoliths and stomach contents removed. The fish were measured (to $0.01 \mathrm{~mm}$ standard length, SL, and $0.001 \mathrm{~g}$ wet mass) and transferred to pre-weighed scintillation vials. Tissue was freeze-dried to a constant weight ( $3 \mathrm{~d}$ ) and transferred to porous alundum thimbles for lipid extraction. Neutral lipids were removed in a modified Soxhlet extraction procedure using petroleum ether as the solvent. The remaining tissue was burned at $600^{\circ} \mathrm{C}$ for determination of ash weight. Homogeneous standards were run with halibut samples during all stages of compositional analysis to ensure temporal stability in laboratory procedures.

Statistical analysis of compositional differences between the delayed and control treatments and between dominant and subordinate fish was conducted with 2-way ANCOVA of lipid mass using body length as the covariate. Lipid mass and body length were logtransformed prior to analysis.

Behavioral observations. Measurements of halibut activity were made by direct observation at the time of feeding and by video-recording from cameras placed directly above the tanks. Direct observations of feeding responsiveness of juvenile halibut (Stoner 2003, Hurst 2004) began in Week 8 of the temperature phase. Each tank was observed for $60 \mathrm{~s}$ following the addition of food, and the time of the first feeding strike was recorded ( $\mathrm{n}=210$ observations in control treatment, $\mathrm{n}=264$ in delayed treatment). Weekly averages of the time to the first feeding strike were used to describe the effect of thermal history on feeding behavior.

Video-recordings of halibut behavior were made during the last $9 \mathrm{wk}$ of both treatments, when temperatures were $10^{\circ} \mathrm{C}$. We videotaped 6 and 5 tanks of the delayed and control treatments, respectively, from above for $15 \mathrm{~min}^{-1}$ for 2 consecutive days. Of the 2 filming days, 1 included feeding (at approximately $12: 00 \mathrm{~h}$ ) followed by an additional $30 \mathrm{~min}$ period of video-recording. On nights of video monitoring, a dim red light was used to allow observations. The same 5 min period from each hour was selected for analysis. Halibut remain motionless on the sediment surface for extended periods, with activity composed primarily of distinct saltatory movements, providing straightforward activity metrics. The number of fish moving $(0,1$ or 2) and the activity score (total count of fish movements) during the 5 min period were used as measures 
of activity level. The 48 hourly observations of each tank were averaged over 6 intervals (2 light and 1 dark period $\mathrm{d}^{-1}$ ). Behavioral observations could not always be reliably attributed to dominant and subordinate fish, and were therefore pooled for analyses. Because of heterogeneity of variances among groups and the interaction between temperature treatment and time, non-parametric Mann-Whitney $U$-tests were used to determine differences in activity between thermal history treatments for each time interval.

\section{RESULTS}

\section{Growth rate}

There were no mortalities among experimental fish, and all fish achieved significant growth during the experiment. As expected, specific growth rates of juvenile halibut were significantly affected by temperature treatment (Fig. 2; 2-way ANOVA, df = 1.36, p <0.01); growth at $2^{\circ} \mathrm{C}$ was less than $25 \%$ of growth at $10^{\circ} \mathrm{C}$. Specific growth rate was not affected by fish rank $(p=0.25)$. Growth in length was significantly affected by both temperature treatment and fish rank $(p<0.05)$. There were no significant interaction effects between temperature treatment and fish rank $(p>0.05)$ on growth in length or mass.

Specific growth rates during the compensation phase were significantly affected by temperature treatment and fish rank (2-way ANOVA, df = 1.36, p < 0.05) but not by their interaction $(p=0.55)$. Compensatory growth of halibut following exposure to low temperatures was evident, as fish previously reared at $2{ }^{\circ} \mathrm{C}$ (delayed treatment) grew in weight an average of $20 \%$ faster than similarly sized control fish. There was no significant interaction effect between temperature treatment and fish rank on length growth $(\mathrm{p}=0.17)$. Growth in length was $16 \%$ greater among delayed fish than among control fish ( $\mathrm{p}<0.01$ ), and $22 \%$ greater among dominant fish than subordinate fish $(p<0.01)$.

\section{Energy reserves}

Lipid energy reserves in juvenile halibut, measured at the end of the experiment, were significantly affected by body length, fish rank and thermal history. The coefficients relating lipid mass to body length were homogeneous among dominant and subordinate fish and temperature treatments $(p=0.488)$. Lipid levels were significantly higher among the subordinate fish than the dominant fish (2-way ANCOVA, $\mathrm{df}=1.34, \mathrm{p}<0.01$ ) and higher among control than growth delayed fish $(\mathrm{p}<0.01)$. These differences be- tween treatments are illustrated in the adjusted mean lipid mass of a $120 \mathrm{~mm}$ SL fish (Fig. 3).

Lipid levels were $19 \%$ higher among the subordinate fish than the dominant fish (2-way ANCOVA, $\mathrm{df}=1.34, \mathrm{p}<0.01)$ and $14 \%$ higher among controls than growth delayed fish $(\mathrm{p}<0.01)$.

\section{Activity patterns}

The feeding responsiveness of juvenile halibut was strongly dependent on water temperature (Fig. 4). In the $10^{\circ} \mathrm{C}$ control tanks, the first feeding strike always occurred within $60 \mathrm{~s}$ of the addition of food, averaging $5.5 \pm 6.7(\mathrm{SE}) \mathrm{s}$. At $2{ }^{\circ} \mathrm{C}$ a feeding strike was observed in the first $60 \mathrm{~s}$ only $39 \%$ of the time. Following the increase to $10^{\circ} \mathrm{C}$, the fraction of feeding responses among delayed fish initiated within $60 \mathrm{~s}$ increased immediately to $90 \%$, reaching $100 \% 5$ wk after tem-
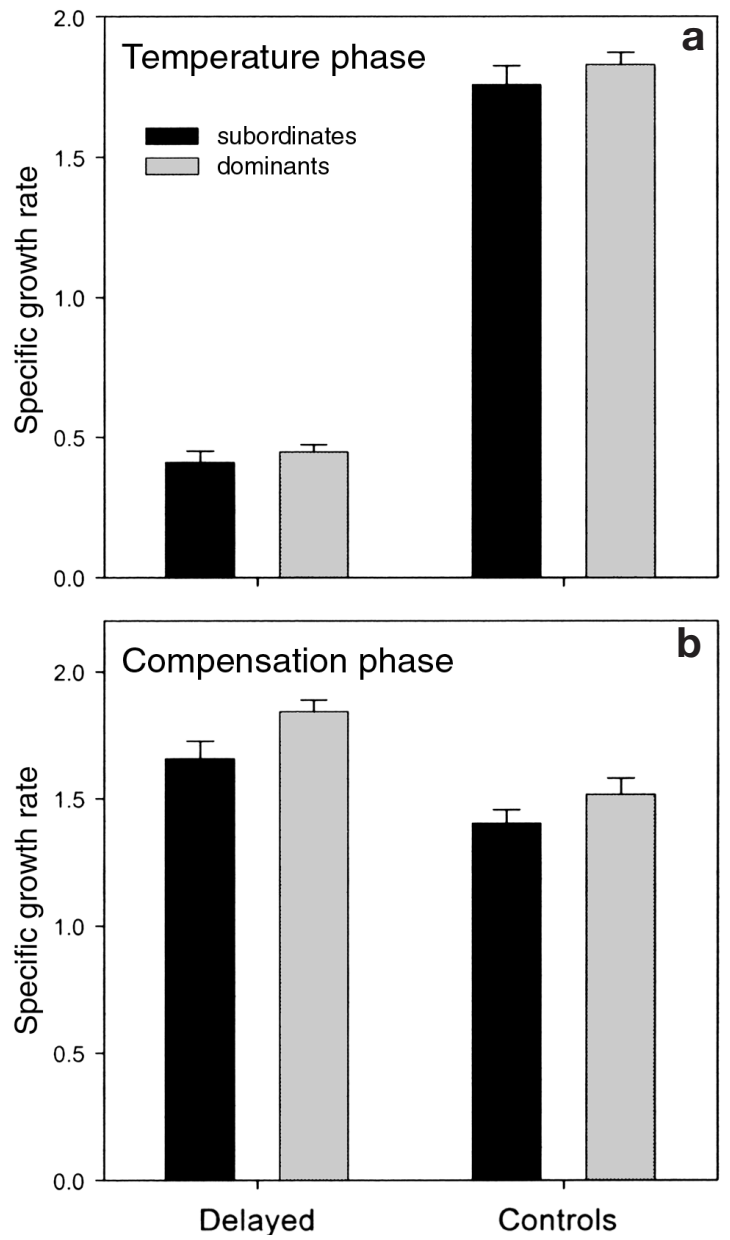

Fig. 2. Hippoglossus stenolepis. Specific growth rates of juveniles in (a) temperature phase and (b) compensation phase. Each bar represents mean (+SE) growth rate of 10 halibut in each treatment-rank group 


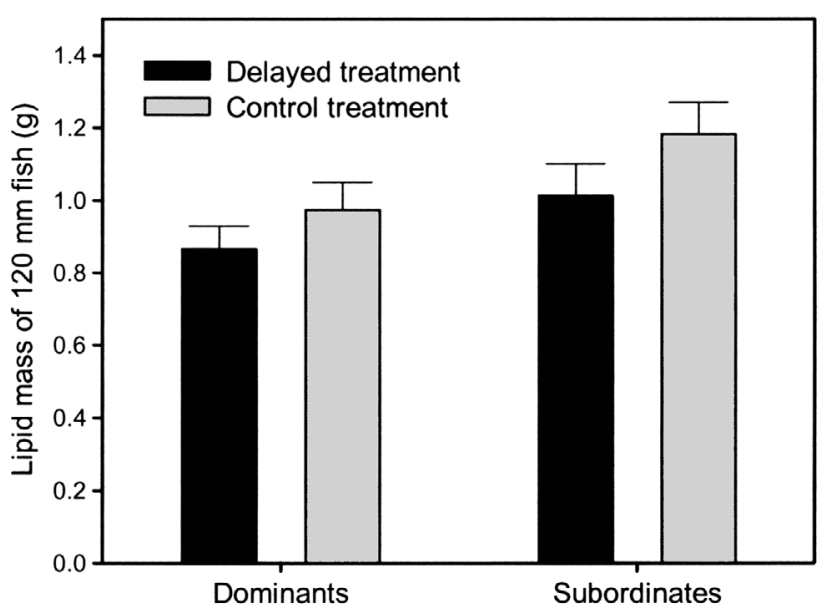

Fig. 3. Hippoglossus stenolepis. Lipid energy reserves in juveniles measured at end of growth experiment. Values are mean (+SE) lipid mass of each group adjusted to $120 \mathrm{~mm}$ standard length fish

perature change. Strike times of the delayed fish during the final 9 wk of the compensation phase were $4.3 \pm 4.8$ (SE) s, not significantly different than those observed for control fish throughout the experiment (ANOVA, df = 1.298, $\mathrm{p}=0.123$ ).

Activity levels of juvenile halibut were affected by growth history, light level and time since feeding (Fig. 5). Activity levels at night (number of fish moving and activity score) were low and independent of experimental treatment and time since feeding (MannWhitney $U$-test, $\mathrm{p}>0.10$ ). Daytime activity immedi-

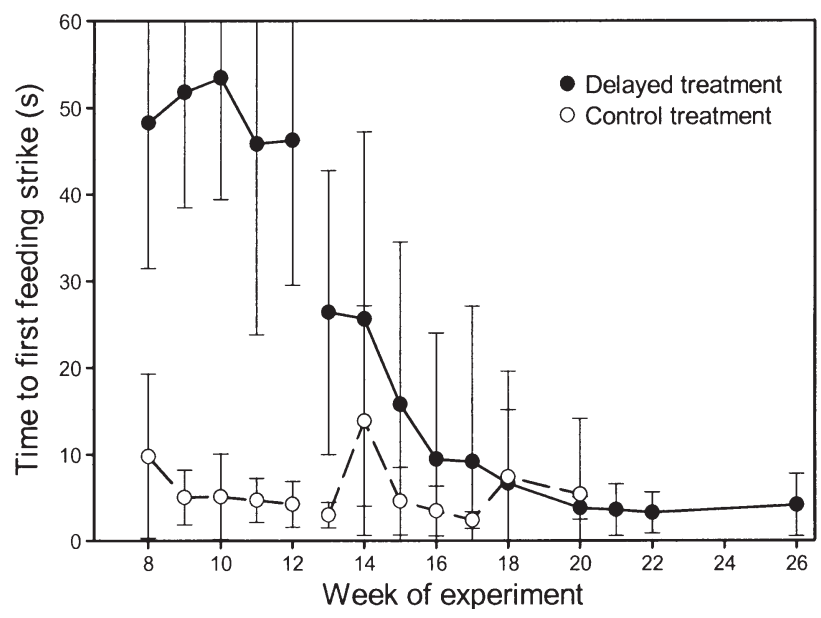

Fig. 4. Hippoglossus stenolepis. Time to first feeding strike of juveniles reared continuously at $10^{\circ} \mathrm{C}(\mathrm{Control})$, or reared initially at $2^{\circ} \mathrm{C}$ and then at $10^{\circ} \mathrm{C}$ (Delayed). Data for temperature and compensation phases are separated by line breaks at Week 12 . Values are weekly means $( \pm \mathrm{SE})$. Maximum value of $60 \mathrm{~s}$ was assigned when feeding was not initiated within 1 min of food introduction

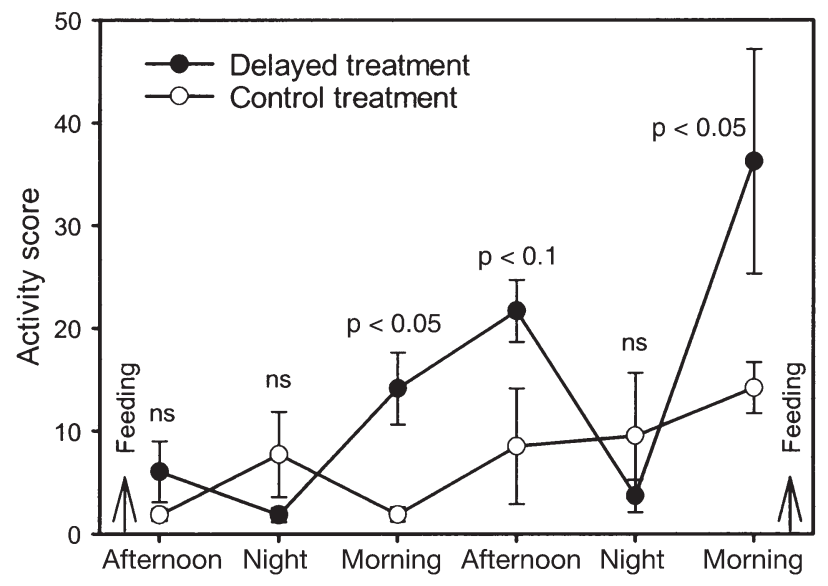

Fig. 5. Hippoglossus stenolepis. Activity score of juveniles at $10^{\circ} \mathrm{C}$ relative to feeding time. Values are means $( \pm \mathrm{SE})$. -: delayed treatment (halibut previously reared at $2^{\circ} \mathrm{C}$ ); O: controls (continuously reared at $10^{\circ} \mathrm{C}$ ). ns: non significant

ately following feeding was also low and did not differ between treatments $(p>0.10)$. Beginning with the morning following feeding, daytime activity increased with time since feeding in both treatments. Activity levels among growth compensating halibut (delayed treatment) were consistently greater (2 to 3 times, $\mathrm{p}<0.10$ ) than among the controls.

\section{DISCUSSION}

The importance of temperature in regulating the growth rates of ectotherms is well known. Cohorts of juvenile fish encountering elevated temperatures can achieve rapid growth, provided sufficient prey resources are available and temperatures do not exceed the species' optimum (King et al. 1999, Sogard \& Olla 2001). Laboratory measurements of growth rate are most commonly conducted under constant temperatures, and bioenergetic models of growth based on such experiments assume that thermal and growth histories are not important components of growth rate variation. Here, we have demonstrated that juvenile halibut exposed to a thermally induced reduction in growth exhibited elevated growth rates relative to controls upon re-acclimation to higher temperatures. This compensatory growth was associated with a reduced level of lipid storage and was accompanied by an increase in daytime activity levels.

Despite its importance as a resource species, there are few laboratory-based estimates of growth potential for juvenile Pacific halibut. However, a retrospective analysis of growth rates suggests that thermal variation plays an important role in regulating the growth of wild halibut (Hagen \& Quinn 1991). Growth rates esti- 
mated from otoliths during the first 2 yr of life were positively correlated with Gulf of Alaska water temperatures. In the temperature phase of this experiment, the specific growth rates of juvenile halibut were 4 times greater at $10^{\circ} \mathrm{C}$ than at $2^{\circ} \mathrm{C}$. The high energy content of the diet used in this experiment may account for the higher growth rates observed here compared to previous observations (Paul et al. 1994, Moles \& Scott 2002).

Juvenile halibut exposed to low temperatures displayed considerable capacity for compensatory growth ( $20 \%$ increase over controls). However, complete compensation, achieving similar body sizes, would have been accomplished only after an extended period, if ever. Following $12 \mathrm{wk}$ of growth, fish reared at $10^{\circ} \mathrm{C}$ were 2.4 times larger (in mass) than fish reared at $2^{\circ} \mathrm{C}$. Assuming maintenance of the observed growth rate differences, the delayed fish would have caught up in body mass with the control fish $35 \mathrm{wk}$ after the temperature change back to $10^{\circ} \mathrm{C}$. Whether the elevated growth rates could be maintained for this duration is unknown. Such a delay in body size recovery was also observed in juvenile Atlantic salmon Salmo salar, which required $20 \mathrm{wk}$ to overcome $3 \mathrm{wk}$ of an $8^{\circ} \mathrm{C}$ temperature reduction (Maclean \& Metcalfe 2001).

Elevated feeding is the most commonly observed mechanism for increasing growth (Ali et al. 2003). Although consumption rates were not routinely measured in this experiment, estimates based on the number of feeding strikes observed in video-recordings during the compensation phase were $61 \%$ higher among delayed fish than controls. In addition, compensatory growth may also be accomplished through other changes in the energy budget, including increased growth efficiency (Hayward et al. 1997) or reduced metabolic expenditures (Sogard \& Olla 2002). The present work suggests that compensatory growth in juvenile halibut may have been accomplished in part by reducing energy allocation to lipid storage. Size-specific lipid levels in juvenile halibut recovering from a thermally induced growth reduction were $14 \%$ lower than in fish reared in constant warm conditions. While this observation could be the direct result of the low temperature exposure, additional data (Hurst 2004) indicates that delayed halibut would have begun the compensation phase with higher storage levels than controls. Dry liver mass of juvenile Pacific halibut reared under similar conditions for 6 to 12 wk at $2^{\circ} \mathrm{C}$ was $17 \%$ higher than in fish reared at $10^{\circ} \mathrm{C}$. Because the liver is a primary site for lipid storage in fishes including halibut (Haug et al. 1988), relative liver weight (hepatosomatic index) is generally presumed to reflect greater energy reserves. Maintenance of higher storage levels at low temperatures has been observed in another flatfish, juvenile turbot Scopthalmus maximus (Burel et al. 1996, Van Ham et al. 2003).
Hence, the reduced storage levels of growth delayed halibut appear to be the result of decreased allocation of energy to reserves in favor of more rapid increases in body length and mass during the period of growth compensation.

The higher activity levels observed during compensatory growth indicate that reductions in metabolic expenditures did not contribute to increased growth rate. Following feeding to satiation, minimal levels of activity were observed in both treatments during the remainder of the daylight period and the following night. On the subsequent day, when fish were not fed, activity levels in the delayed treatment were significantly higher than in controls. The elevated activity levels of fish undergoing compensatory growth are interpreted as increased prey searching activity. These activity levels are similar to those observed in halibut maintained on sub-maximal rations (T. P. Hurst unpubl. data), suggesting that delayed fish in the compensation phase might have achieved even higher growth under a daily (rather than alternate days) feeding schedule. Interestingly, the increased activity of growth compensating halibut did not translate into significantly faster strike times when food was made available. Similar strike time measures have been used successfully to reflect variation in feeding motivation in both juvenile (5 to $13 \mathrm{~cm}$, Hurst 2004) and subadult halibut $(40 \mathrm{~cm}$, Stoner 2003). The rapidity (usually less than $10 \mathrm{~s}$ ) and similarity in strike times between growth treatments during the compensation phase was probably due to highly visible food being added throughout the tank, so that searching was not necessary to encounter food.

Like other organisms, Pacific halibut engage in complex social interactions, displaying both social facilitation in feeding and size-based competition for prey (Stoner \& Ottmar 2004). While there is no evidence that halibut establish persistent dominance hierarchies in the wild, we observed differences in the growth and behavior of juvenile halibut consistent with the presence of a dominant-subordinate relationship between the 2 fish in each tank. Behavioral observations indicated that the larger fish generally initiated feeding before the smaller fish. Often the smaller fish did not begin feeding until feeding activity of the larger fish ceased. Growth rates were higher among the dominant fish throughout the experiment, with the difference in growth increasing with increasing size disparity.

Counter to the general observation that fast growing fish accumulate greater levels of energy reserves (Pedersen \& Hislop 2001, Sogard \& Spencer 2004), lipid levels measured at the end of the experiment, corrected for body size differences, were significantly higher among subordinates than dominants in both delayed and control fish. There are 2 potential explanations for this. 
Based on observations of overwintering birds, Clark \& Ekman (1995) present a general model whereby variability in access to feeding opportunities, predation risk and metabolic expenditures favor the maintenance of higher energy stores in subordinate than in dominant individuals. Alternatively, reduced storage among the faster-growing dominant fish may be analogous to the reduced storage among fish undergoing compensatory growth, with reduced energy storage representing a general consequence of rapid growth in halibut.

Several models describing the triggering mechanism for compensatory growth have focused on some form of lipostatic regulation (Broekhuizen et al. 1994, Johansen et al. 2001). These models incorporate variation in the mass of storage tissues relative to body size, having been developed in response to numerous experiments involving the starvation and re-feeding of fishes. The growth spurt in the present experiment apparently occurred in fish with high size-specific energy reserves resulting from to previous rearing at low temperatures, suggesting that alternative triggering mechanisms must also exist. The lack of seasonal cues in the experiment, such as photoperiod changes, suggests that the compensatory-growth response in juvenile halibut was triggered directly by the thermal or growth history of the fish. Furthermore, the results provide empirical support for the suggestion that variation in energy storage levels observed in wild populations may be related to patterns of growth history (Post \& Parkinson 2001, Hurst \& Conover 2003).

The ability to elevate feeding and growth rates in response to specific environmental and physiological situations has been taken as evidence that growth is strategically regulated to balance the benefits of larger body size with the potential costs of growth (Abrams et al. 1996, Arendt 1997). Traditionally, exposure to predators during foraging has been assumed to represent the major trade-off with growth (Sih 1987). As juvenile flatfish use burial and crypsis as primary antipredator strategies, the increased activity levels observed in growth compensating fish suggests that such a predation cost exists for juvenile halibut. In addition, recent experimental work on the evolution of growth rates in fishes has identified several physiological costs of rapid growth in general, and compensatory growth in particular. These include reduced swimming speed (Billerbeck et al. 2001), increased vulnerability to predation (Lankford et al. 2001, Munch \& Conover 2003) and depressed immune system function (Imsland et al. 2002). Our results indicate that a reduction in size-specific energy reserves may represent an additional consequence for some species of fish engaging in compensatory growth.

This experiment has demonstrated the ecological consequences of living in environments with strong spatial or temporal variation in ocean temperatures.
While the low temperature exposure was not lethal to juvenile halibut, the consequent growth reduction probably results in higher rates of size-dependent predation (Anderson 1988, Sogard 1997). Even with the ability to compensate for periods of reduced growth, delayed halibut face considerable obstacles to survival and recruitment, as the estimated time to complete compensation was at least 3 times the duration of the growth reduction. Further, the increased foraging activity during the growth compensation period may result in additional predation risk (Ryer et al. 2004). Finally, the diversion of assimilated energy from lipid storage to growth may increase vulnerability to starvation during subsequent periods of prey scarcity.

Acknowledgements. We thank T. Tripp and E. Munk for assistance with capture and transport of juvenile halibut. E. Munk and B. Stevens provided logistical support and laboratory space in Kodiak. M. Davis arranged collection and transportation permits and oversaw quarantine procedures. M. Ottmar and E. Sturm assisted with fish rearing in Newport prior to experiments. S. Hains made activity measurements from video-recordings. J. Buckel and M. Davis provided valuable comments on earlier drafts of this manuscript.

\section{LITERATURE CITED}

Abrams PA, Leimar O, Nylin S, Wiklund C (1996) The effect of flexible growth rates on optimal sizes and development times in a seasonal environment. Am Nat 147:381-395

Ali M, Nicieza A, Wootton RJ (2003) Compensatory growth in fishes: a response to growth depression. Fish Fish Ser 4: $147-190$

Anderson JT (1988) A review of size dependent survival during pre-recruit stages of fishes in relation to recruitment. J Northwest Atl Fish Sci 8:55-66

Arendt J (1997) Adaptive intrinsic growth rates: an integration across taxa. Q Rev Biol 72:149-177

Bejda A, Phelan BA, Studholm AL (1992) The effect of oxygen on the growth of young-of-the-year winter flounder, Pseudopleuronectes americanus. Environ Biol Fishes 34:321-327

Bergman MJN, van der Veer HW, Zijlstra JJ (1988) Plaice nurseries: effects on recruitment. J Fish Biol 33A:201-218

Billerbeck JM, Lankford TE, Conover DO (2001) Evolution of intrinsic growth and energy acquisition rates. I. Trade-offs with swimming performance in Menidia menidia. Evolution 55:1863-1872

Broekhuizen N, Gurney WSC, Jones A, Bryant AD (1994) Modelling compensatory growth. Funct Ecol 8:770-782

Buckel JA, Letcher BH, Conover DO (1998) Effects of a delayed onset of piscivory on the size of age-0 bluefish. Trans Am Fish Soc 127:576-587

Burel C, Person-Le Ruyet J, Gamumet F, Le Roux A, Sévère A, Boeuf G (1996) Effects of temperature on growth and metabolism in juvenile turbot. J Fish Biol 49:678-692

Chui TS, Chen CS (2001) Growth and temporal variation of two Japanese anchovy cohorts during their recruitment to the East China Sea. Fish Res 53:1-15

Clark CW, Ekman J (1995) Dominant and subordinate fattening strategies: a dynamic game. Oikos 72:205-212

Foss A, Imsland AK (2002) Compensatory growth in the spotted wolffish Anarhichas minor (Olafsen) after a period of limited oxygen supply. Aquac Res 33:1097-1101 
Gaylord TG, Gatlin DM (2001) Dietary protein and energy modifications to maximize compensatory growth of channel catfish (Ictalurus punctatus). Aquaculture 194:337-348

Hagen PT, Quinn II TJ (1991) Long-term growth dynamics of young Pacific halibut: evidence of temperature-induced variation. Fish Res 11:283-306

Haug T, Ringø E, Pettersen GW (1988) Total lipid and fatty acid composition of polar and neutral lipids in different tissues of Atlantic halibut, Hippoglossus hippoglossus (L.). Sarsia 73:163-168

Hayward RS, Notlie DB, Wang N (1997) Use of compensatory growth to double hybrid sunfish growth rates. Trans Am Fish Soc 126:316-322

Hurst TP (2004) Temperature and state-dependence of feeding and gastric evacuation in juvenile Pacific halibut. J Fish Biol 65:157-169

Hurst TP, Conover DO (2003) Seasonal and interannual variation in the allometry of energy allocation in juvenile striped bass. Ecology 84:3360-3369

Hurst TP, Schultz ET, Conover DO (2000) Seasonal energy dynamics of young-of-the-year Hudson River striped bass. Trans Am Fish Soc 129:145-157

Imsland AK, Jonassen TM, Langston A, Hoare R, Wergeland H, Fitzgerald R, Mulcahy M, Steffansson SO (2002) The interrelation of growth and disease resistance of different populations of juvenile Atlantic halibut (Hippoglossus hippoglossus L.). Aquaculture 204:167-177

Jobling M, Meloy OH, dos Santos J, Christiansen B (1994) The compensatory growth response of the Atlantic cod: effects of nutritional history. Aquac Int 2:75-90

Johansen SJS, Ekli M, Stagnes B, Jobling M (2001) Weight gain and lipostatic deposition in Atlantic salmon, Salmo salar, during compensatory growth: evidence for lipostatic regulation? Aquac Res 32:963-974

Kamermans P, Guindon KY, Miller JM (1995) Importance of food availability for growth of juvenile southern flounder (Paralichthys lethostigma) in the Pamlico River Estuary, North Carolina, USA. Neth J Sea Res 34:101-109

King JR, Shuter BJ, Zimmerman AP (1999) Empirical links between thermal habitat, fish growth, and climate change. Trans Am Fish Soc 128:656-665

Lankford TE, Billerbeck JM, Conover DO (2001) Evolution of intrinsic growth and energy acquisition rates. II. Tradeoffs with vulnerability to predation in Menidia menidia. Evolution 55:1873-1881

Luchin VA, Menovshchikov VA, Lavrentiev VM, Reed RK (1999) Thermohaline structure and water masses in the Bering Sea. In: Loughlin TR, Ohtani K (eds) Dynamics of the Bering Sea. University of Alaska (Sea Grant), Fairbanks, AK, p 61-91

Maclean A, Metcalfe NB (2001) Social status, access to food, and compensatory growth in juvenile Atlantic salmon. J Fish Biol 58:1331-1346

Moles A, Scott R (2002) Growth and behavior of juvenile Alaskan flatfishes in the laboratory. Northwest Sci 76:41-45

Mortensen A, Damsgård B (1993) Compensatory growth and weight segregation following light and temperature manipulation of juvenile Atlantic salmon (Salmo salar L.) and Arctic charr (Salvelinus alpinus L.). Aquaculture 114:261-272

Munch SB, Conover DO (2003) Rapid growth results in increased susceptibility to predation in Menidia menidia. Evolution 57:2119-2127

Nicieza A, Metcalfe NB (1997) Growth compensation in juvenile Atlantic salmon: responses to depressed temperature and food availability. Ecology 78:2385-2400

Norcross BL, Holladay BA, Müter FJ (1995) Nursery area characteristics of pleuronectids in coastal Alaska, USA.

Editorial responsibility: Kenneth Heck (Contributing Editor), Dauphin Island, Alabama, USA
Neth J Sea Res 1995:161-175

Norcross BL, Müter FJ, Holladay BA (1997) Habitat models of juvenile pleuronectids around Kodiak Island, Alaska. Fish Bull 95:504-520

Ottersen G, Loeng H (2000) Covariability in early growth and year-class strength of Barents Sea cod, haddock, and herring: the environmental link. ICES J Mar Sci 57:339-348

Paul AJ, Paul JM, Smith RL (1994) Energy and ration requirements of juvenile Pacific halibut (Hippoglossus stenolepis) based on energy consumption and growth rates. J Fish Biol 44:1023-1031

Paul AJ, Paul JM, Smith RL (1995) Compensatory growth in Alaska yellowfin sole, Pleuronectes asper, following food deprivation. J Fish Biol 46:442-448

Pedersen J, Hislop JRG (2001) Seasonal variations in the energy density of fishes in the North Sea. J Fish Biol 59:380-389

Post JR, Parkinson EA (2001) Energy allocation strategy in young fish: allometry and survival. Ecology 82:1040-1051

Reed RK, Schumacher JD (1986) Physical oceanography. In: Hood DW, Zimmerman ST (eds) The gulf of alaska: physical environment and biological resources. United States Ocean Assessments Division, Anchorage, AK, p 57-75

Rutherford ES, Houde ED (1995) The influence of temperature on cohort-specific growth, survival, and recruitment of striped bass, Morone saxatilis, larvae in Chesapeake Bay. Fish Bull (Wash DC) 93:315-332

Ryer CH, Stoner AW, Titgen RH (2004) Behavioral mechanisms underlying the refuge value of benthic structure for two flatfishes with differing anti-predator strategies. Mar Ecol Prog Ser 268:231-243

Sih A (1987) Predator and prey lifestyles: an evolutionary and ecological overview. In: Kerfoot WC, Sih A (eds) Predation: direct and indirect impacts on aquatic communities. University of New England Press, Hanover, NH, p 203-224

Sogard SM (1997) Size-selective mortality in the juvenile stage of teleost fishes: a review. Bull Mar Sci 60:1129-1157

Sogard SM, Olla BL (2001) Growth and behavioral responses to elevated temperatures by sablefish Anaplopoms fimbria and the interactive role of food availability. Mar Ecol Prog Ser 217:121-134

Sogard SM, Olla BL (2002) Contrasts in the capacity and underlying mechanisms for compensatory growth in two pelagic marine fishes. Mar Ecol Prog Ser 243:165-177

Sogard SM, Spencer ML (2004) Energy allocation in juvenile sablefish: effects of temperature, ration and body size. J Fish Biol 64:1-13

Stabeno PJ, Bond NA, Kachel NB, Salo SA, Schumacher JD (2001) On the temporal variability of the physical environment over the south-eastern Bering Sea. Fish Oceanogr 10:81-98

Stoner AW (2003) Hunger and light level alter response to bait by Pacific halibut: laboratory analysis of detection, location and attack. J Fish Biol 62:1176-1193

Stoner AW, Abookire AA (2002) Sediment preferences and size-specific distribution of young-of-the-year Pacific halibut in an Alaskan estuary. J Fish Biol 61:540-559

Stoner AW, Ottmar ML (2004) Fish density and size alter Pacific halibut feeding: implications for stock assessment. J Fish Biol 64:1712-1724

van der Veer HW, Berghahn R, Rijnsdorp AD (1994) Impact of juvenile growth on recruitment in flatfish. Neth J Sea Res 32:153-173

Van Ham EH, Berntssen MHG, Imsland AK, Parpoura AC, Bonga SEW, Steffansson SO (2003) The influence of temperature and ration on growth, feed conversion, body composition and nutrient retention of juvenile turbot (Scopthalmus maximus). Aquaculture 217:547-558

Submitted: March 29, 2004; Accepted: January 24, 2005

Proofs received from author(s): April 15, 2005 